\title{
STUDENTS' PERCEPTIONS OF USING GOOGLE CLASSROOM DURING THE COVID-19 PANDEMIC
}

\author{
Annafi Annanda Oktaria ${ }^{*}$, Laksmita Rohmayadevi ${ }^{2}$ \\ 1,2 Universitas Ahmad Dahlan, Yogyakarta, Indonesia \\ 1*anna.nafi.okta@gmail.com
}

\begin{tabular}{l}
\hline Article Info \\
\hline Article history \\
Received January 18, 2021 \\
Revised January 20, 2021 \\
Accepted February 9, 2021 \\
\hline
\end{tabular}

Keywords: Covid-19; Educational technology; English education; Online Learning

\begin{abstract}
Technology has impacted in most of the sectors, including the education field. Nowadays, many schools have incorporated technology through Information and Communication Technologies (ICT) into learning. This research investigates students' perception of Google Classroom as a learning tool during the covid-19 pandemic. The method used in this research is quantitative descriptive through an online questionnaire and online deep interview sessions with students from SMP Muhammadiyah Yogyakarta. Twenty-eight students have been joining Google Classroom in English learning for at least one term during the covid-19 pandemic. Five students also interviewed to seek more information about their experiences using Google Classroom. Findings showed that several factors influence the students' online learning process in a covid-19 pandemic, namely, usefulness, ease of use, ease of learning, and satisfaction. In general, Google Classroom is very useful in improving students' skills, abilities, discipline, and independent learning through teaching materials.
\end{abstract}

\section{INTRODUCTION}

The world is shocked by the emerge of an epidemic caused by a virus called corona or what is best known as Covid-19. It started to become epidemic on December 31, 2019, in Wuhan, Hubei province, China. A few months later, or on March 11, 2020, the World Health Organization (WHO) declared that these diseases had become a global pandemic; this happened because thousands of people worldwide had been exposed, even thousands of people had become victims.

According to Agung and Surtikanti (2020), the pandemic is a disease that is spreading in multiple countries around the world at the same time. This disease is spreading rapidly, and detecting people who have been exposed to the virus is very hard. It makes the numbers of victims rise significantly. The complexity of this epidemic's handling has led world leaders to implement a policy to break the chain of distribution of covid-19. This situation has affected various sectors, despite the effect on economic, social distancing and a complete lockdown becomes a tough choice for many countries to prevent the spread of covid-19. Education also became a victim of the implementation of these policies. Since the enactment of social distancing, teaching and learning activities in schools have also been abolished. 
The policies taken by many countries, including Indonesia, by dismissing all direct educational activities, make the government and related institutions must present alternative educational processes for students and students who cannot carry out the educational process in educational institutions. Based on UNESCO data, currently, a total of 39 countries have implemented school closures, with the total number of students affected reaching $421,388,462$ children.

The Indonesian Minister of Education and Culture, Nadiem Makarim, issued a Circular Note for schools and other educational institutions, including higher education, to temporarily stop the schools' conventional teaching and learning activities during pandemic covid-19 and encourage lessons to be conducted from home through e-learning. He recommended that teachers use various e-learning platforms such as Rumah Belajar, Quipper School, Ruang Guru, Google Classroom, Zoom, and soon. Nowadays, those elearning platforms achieve popularity in Indonesia because they are widely used and installed. Online learning becomes one of the most current and potential issues.

Technology-based learning is the choice during epidemics. Almost all schools throughout the world implement online-based learning. Online-based learning is not a new thing in this era. Educators are required to have skills in teaching and have skill in using instructional media. In this era, several aspects must be mastered by educators, including mastery of internet technology. The internet has become an effective and efficient part of getting and exchanging data and information without looking at space and time dimensions. The development of internet technology currently affects various aspects of life, including aspects of government, economic, social, and education. The current educational goals are inseparable from technological development demands as competencies that teachers and students must provide.

Teachers use several learning applications to support online-based learning, such as Google Classroom. Google Classroom as a free tool offers various features which encourage student-teacher interaction through a virtual online class. It helps the teacher and also students to learn during Pandemic Covid-19. However, based on the writer's observation, some problems happened during the learning process using google classroom. Some students did not join google classroom because of the lousy internet connection.

Moreover, some of the students did not know how to use google classroom. It is needed to know students' perception of google classroom as a learning tool to evaluate the learning process during pandemic covid-19. This paper describes students' perceptions of google classrooms during the Covid-19 Pandemic, where students' perception was presented based on their experiences.

Perception is the experience of object, event, and relationship acquired by resuming information and interpreting a message. (Ridho et al., 2019) It explains perception, giving meaning to stimulus-response in resuming information and predicting a message that 
involves attention, hope, motivation, and memory. Following it, (Agung \& Surtikanti, 2020) develops perception as a phase of the whole process of action, which allows us to adjust our activities to the world we live in. Here, the students' perception can be described as the developed opinion after having a specific experience that needs adjustment.

Knowing students' perception is very important because this also means for teachers or lecturers to evaluate after knowing the results of student perceptions. As stated by (Qudratullah et al., 2020), the student's perception is crucial for evaluating the teaching effectiveness. After knowing students' perception, teachers can change what is not liked by students and improve what has been liked by students, whether it is about how to teach or how to deliver material to students. Thus, the student's perception is critical, especially for teachers or lecturers.

In this research, the student's perception focused on the usefulness, ease of use, ease of learning, satisfaction of using google classroom in online learning. Those factors are necessary to bring the students' perception of online learning to be more contextual with this research's needs.

Rozak and Albantani (2018) found that this application provides an opportunity for lecturers or teachers to explore the scientific ideas they have for students. (Ocampo et al., 2017) suggests that learning through Google classroom is a part of a strategy that uses technology to facilitate faculty and students in the learning process. In Google Classroom, lecturers can provide materials on the subject taught.

The lecturers can post some teaching materials, assign tasks for students, and upload the students' grade to see the scores obtained in the course immediately. Besides, Google Classroom can be an alternative to postpone meetings when the lecturers are outside the city or are busy during class hours. Alim et al. (2019)) found that Google Classroom also minimizes the costs incurred due to more affordable stationery and other materials and can minimize time-released energy. In short, the time and energy spent by Google Classroom users will be lesser than usual. However, one of the significant barriers to realizing the effectiveness of learning from online classes is that not all students have an online account. Some students do not have smartphones or a data plan for attending online discussion sessions.

Ventayen et al. (2018) Google classroom is one of the free services by Google in the Gsuite for Education plan. It promotes paperless instruction for streamlining assignments, boosts collaboration and fosters seamless communication to make teaching more productive and meaningful. This study aims to identify the usability of the Google Classroom application as an online learning tool. This application can be used on a smartphone where both lecturer and students can easily download it and log in. The lecturer only needs to create a class and share the class code with the students to let them join the class created. Students can submit their assignment easily through this application, revise their assignment, 
and check their scores given by the lecturer. It also has some benefits, such as paperless. It can be accessed anywhere and everywhere as long as there is an internet connection and from any devices, communicate between lecturer and students, give feedback to students, and personalized learning. It has a learning feature that makes the lecturer create and handle assignments actively and provide feedback to students. Google classroom application makes it easier for lecturers to handle students' work. It is beneficial for both lecturers and students because it is easy and straightforward to use.

Some research has been conducted related to the use of Google Classroom. Harjanto and Sumarni (2019) presented the teacher's perception towards Google Classroom as it is only a facilitation tool, for example, for uploading the document and giving announcements. Unfortunately, teachers still see this application as ineffective in terms of the lack of user-friendliness.

Another research was conducted by Alim et al. (2019) at Daffodil International University, which mainly emphasized teachers' and students' perceptions of using Google Classroom. Generally, teachers use Google Classroom as the university requires it. The use of Google Classroom creates a better interaction between teacher and students. In contrast, students believe that this platform is helpful since they can quickly get the teachers' learning materials uploaded. There are also several studies focus on the effectiveness of E-learning Moodle, Google Classroom and Edmodo (Hakim, 2016), optimization of using Google Classroom as a learning media (Soni et al., 2018)), Google classroom as an alternative way to enhance learning quality (Sewang, 2017), and Google Classroom as a media for Improving Attainment of Graduate Attributes (Madhavi et al., 2018).

\section{METHODS}

The method used in this research is quantitative descriptive through an online questionnaire and online deep interview sessions with students from SMP Muhammadiyah Yogyakarta. This study included 28 students who have been joining Google Classroom in English learning for at least one term during the covid-19 pandemic. The survey was given to students to know their perception while using google classroom (Asnawi, 2018).

This study collected data through the analysis of students' perceptions based on their personal experience during online learning. The survey made in google form then shared with the students. A further interview conducted to get more profound answers from the students. According to Creswell and Clark (2007), the data were collected through an indepth interview phase to know more about students' perception while using Google Classroom in the online learning process. This interview was conducted with the student's consent.

In this study, the researchers shared the instruments with the students and interviewed some students. From the result of the instrument and the interview, the researchers analyzed 
the data. Furthermore, the obtained data were analyzed to describe the information collected so that the information can be understood not only by the researchers but also by those who seek the results of this research. The data were thematically analyzed to develop a communication effectiveness framework to understand the phenomenon investigated. Glaser and Strauss (2017) stated that Data analysis conducted after the interviews completed, and the researchers analyzed thematically to explain the findings according to the framework.

\section{RESULTS AND DISCUSSION}

\section{RESULT}

\subsection{Student's Perception}

Table 1. Recapitulation of students' survey

\begin{tabular}{lllll}
\hline Factors & $\begin{array}{l}\text { RD } \\
(\%)\end{array}$ & $\begin{array}{l}\text { D } \\
(\%)\end{array}$ & $\begin{array}{l}\text { A } \\
(\%)\end{array}$ & $\begin{array}{l}\text { RA } \\
(\mathbf{\%})\end{array}$ \\
\hline Usefulness & 0 & 9.0 & 60.5 & 30.5 \\
Ease of Use & 0 & 14.03 & 65.25 & 20.72 \\
Ease of Learning & 0 & 9.1 & 55.05 & 35.85 \\
Satisfaction & 0 & 18.48 & 54.82 & 26.70 \\
\hline
\end{tabular}

The table above shows that $60.5 \%$ of participants agreed that this Google Classroom is helpful within the factor of usefulness. While the easiness experience when using, $65,25 \%$ of them agree that the application is easy to use. The next factor also agrees that to learn to use the app, 55,05\% of the students went through easiness. Lastly, the level of satisfaction, $54,82 \%$ of the students' experience that they are satisfied.

\subsection{Usefulness}

The finding showed that $60,5 \%$ of students agree that this Google Classroom is helpful within the factor of usefulness. Students can use Google Classroom as a resource to store the document materials. Besides, after the lesson, some teachers also liked to post the materials presented in the class as a review to access them once the classroom learning session ended. Students can learn to follow up on exercises and projects from their teachers.

Another finding showed that when the teacher shared materials before the class, it intended to be pre-reading materials to further students understand the lesson's topic. It is beneficial to activate their background knowledge before they come into the classroom discussion. Besides, after the lesson, some teachers also liked to post the materials presented in the class as a review, so students can access them once the classroom learning session ended. 
For the productivity of learning the students, google classrooms make very much convenient and appropriate for the learning process. Based on the interview results, some students agreed that feedback they got via Google Classroom helped them improve their works; however, another student disagreed since they said that some feedback only focuses on surface-level, which did not improve their works. Some students also said that in an EFL environment where English not used for everyday conversation, having Google Classroom as supporting media to learn is very useful.

\subsection{Ease of Use}

Students' experience of easiness when using $65,25 \%$ of them agree that the application is easy to use. It means, in general, students agreed that this platform is substantially ubiquitous in regards to their learning activities since this application is accessible through their laptops or smartphones with different kinds of operating systems (OS). To operate Google Classroom is easy for them; they do not have any essential difficulties operating the features.

Based on the results from the interview, some students said that google classroom is easy to use. Besides, all materials, students' tasks and quizzes can record well. So students can quickly check previous material that they have learnt. They can also see their score when they do some practice in google classroom. It can be interpreted as students feel that the Google classroom helps them submit the assignment because of the Google classroom, which can save time and effort while doing and submitting the assignment electronically. Students also can interact with others on the discussion board, which encourages them to have better collaboration. They can discuss the task or project online.

\subsection{Ease of Learning}

$55,05 \%$ of the students went through easiness when using google classroom. Dealing with google application is not something new for the students. They have kept in touch with a g-mail account, google drive and other features for many years. It is the same thing as using Google Classroom, where they do not find any significant difficulty even though this platform is considered new. They can use google classroom as a tool for learning quickly.

Based on the results from the interview, students said accessing Google Classroom is very simple. They can access all the Google Classroom features in any forms of gadgets, such as a personal computer or smartphone. It is integrated with a Gmail account which connects everything to it. Meanwhile, Google Classroom was relatively simple because it gave several options on accessibility. If the students failed to install the application, it could still access through email and a web browser. If they had no signal or electricity, all the given explanation, material, and quiz were within their reach when they had a chance to access it. 


\subsection{Satisfaction}

For the level of satisfaction, $54,82 \%$ of the students experience that they are satisfied. Google Classroom gets immediate feedback indeed a great platform as an effective tool for learning because of its features and benefits such as active participation in online class activities, easy to use features in submitting online tasks, easy to access reference materials and an increase in student motivation because of online activities and discussions. The results from the questionnaire were also by the results of the interview. The majority of interviewees agreed that Google Classroom is beneficial for them to learn English outside the classroom. They said that they had an English environment even though they were not at school.

The material and assignments delivery in online learning was relatively good. The students thought that the delivered material and assignment were relevant to the course. The teachers also provided discussion sessions to answer the students' questions. However, several students said they could hardly understand the direction and materials provided in the assignments; conventional learning seemed more interesting. They argued that through the face to face meeting, they could listen and watch the lecturer's explanation easily. In line with this, Rosenblit (2006) says that humans' need to socialize is essential. It explains why most students prefer to study in classrooms.

\section{DISCUSSION}

The implementation of the utilization of Google Classroom itself ran successfully because of three reasons. Firstly, the policies taken by many countries, including Indonesia, by dismissing all direct educational activities, make the government and related institutions must present alternative educational processes for students and students who cannot carry out the educational process in educational institutions. It makes many schools hold an online learning class for students. The students must study from home using media online like google classroom. Google classroom becomes one of the media online learning that is chosen because of the usefulness. Google Classroom app is handy for online teaching and learning and can be obtained for free of charge and used on any device. One of the sophistications of this application is that it can be used collaboratively with other groups. (Izenstark \& Leahy, 2015) found that there are so many advantages of using Google Classroom as one of the Learning Management Systems (LMS).

Secondly, teachers have attended the professional development program in which they acquired knowledge and practices on using Google Classroom at the beginning of the academic year. Teachers were invited to attend the workshop, which started with the introduction of Google Classroom, benefits, and operating it to support the learning process. From that program, teachers obtained a deeper understanding of the application; hence, they could maximize its operation. (Mizell, 2014) emphasizes that professional development becomes a school's effort to upgrade the educators' skills to accommodate students' needs. 
As it expected that students would fully achieve their satisfying results because teachers provide them with the best method to suit their interest.

Finally, during the COVID-19 pandemic, the government advised children to study at home. Nevertheless, that does not mean schools are closed. Instead, the learning process that is usually done face-to-face is replaced online. Since that school held an online learning class, the students must join google classrooms to get material and do the teacher's task. In this case, parents must accompany their children while studying. Their parents have an essential role in accompanying students learning using google classroom.

\section{CONCLUSION}

The pandemic of COVID-19 has created a big tide of the paradigm shift in Indonesia's education system: physical to internet-based classrooms. The digital classroom appears to be the perfect answer for the sake of people's health. This condition forces teachers and students to work and study from home. In reality, the shift presents a significant challenge, especially for those who are in the least-developed regions. The current study concludes that Google Classroom is an effective tool for learning because it can help students improve their learning through active participation in online discussion and tasks. The findings showed that most participants responded positively and accepted Google Classroom as a meaningful and straightforward learning platform that enabled them to learn anywhere and anytime without face-to-face interaction with teachers and other classmates. Google Classroom is easy to use because students can take the assignment, submit the assignment, quiz, and do tasks online. Students like to use it due to its simplicity in supporting their learning.

Furthermore, most participants agreed that Google Classroom is a good learning tool to supplement face to face discussions and a good collaboration platform for students and teachers. In conclusion, Google Classroom is very useful to improve every student's abilities and competencies. Students should learn on their own, except through instruction. Students can discover new stuff by needing active learning from Google School. This application is used effectively. However, many technological restrictions, such as the students of any group who cannot access the lecturers' account, also have limited access to smartphones. Besides, Wifi availability on campus is still limited. Some students do not have a suitable data plan for taking part in online discussions, and some students even submit their assignments from their friend's account. To summarise, students see Google Application in the classroom optimistic, and that Brings good learning. The recommendation to use Google Classroom is not all about the valuable Utility resource, but it also allows students to use the features more creatively to create effective learning. Finally, this study confirms that Google Classroom is very useful in improving students' skills, abilities, discipline, and independent learning through teaching materials. 


\section{REFERENCES:}

Agung, A. S. N., \& Surtikanti, M. W. (2020). Students' Perception of Online Learning during COVID-19 Pandemic: A Case Study on the English Students of STKIP Pamane Talino. SOSHUM : Jurnal Sosial Dan Humaniora, 10(2), 225-235.

https://doi.org/10.31940/soshum.v10i2.1316

Alim, N., Linda, W., Gunawan, F., \& Saad, M. S. M. (2019). The effectiveness of Google classroom as an instructional media: A case of state Islamic institute of Kendari, Indonesia. Humanities and Social Sciences Reviews, 7(2), 240-246.

https://doi.org/10.18510/hssr.2019.7227

Asnawi, N. (2018). Pengukuran Usability Aplikasi Google Classroom Sebagai E-learning Menggunakan USE Questionnaire (Studi Kasus: Prodi Sistem Informasi UNIPMA). RESEARCH : Computer, Information System \& Technology Management, 1 (1), 17. https://doi.org/10.25273/research.v1i1.2451

Chen, Y. \& Hoshower, L.B. (2003). Student Evaluation of teaching effectiveness: An Assessment of student's perception and motivation. Assessment \& Evaluation in Higher Education, 28 (1), 71-88.

Creswell, J. W., \& Clark, V. L. P. (2007). Designing and Conducting Mixed Methods Research. Australian and New Zealand Journal of Public Health, 31 (4), 388-388. https://doi.org/10.1111/j.1753-6405.2007.00096.x

Etherington, D., 2017. Google Classroom now lets anyone school anyone else | TechCrunch. Retrieved November 20, 2019, from https://techcrunch.com/2017/04/27/googleclassroomnow-lets-anyone-school-anyone-else/.

Glaser, B.G. and Strauss, A.L. (2017) Discovery of Grounded Theory: Strategies for Qualitative Research. Routledge, New York.

Hakim, A. B. (2016). Efektifitas Penggunaan E-Learning Moodle, Google Classroom Dan Edmodo. I-STATEMENT, 2(1).

Harjanto, A. S., \& Sumarni, S. (2019). Teacher's Experiences on The Use of Google Classroom. 3rd English Language and Literature International Conference (Ellis), 3, 172-178.

Hausammann, P.B. (2017). Beginning Google Classroom and the Paperless Classroom. Retrieved from https://www.fetc.org/materials/W01 3.pdf

Inove, M., \& Pengnate, W. (2018, May). Belief in foreign language learning and satisfaction with using Google classroom to submit online homework of undergraduate students. In 2018 5th International Conference on Business and Industrial Research (ICBIR) (pp. 618621). IEEE.

Izenstark, A., \& Leahy, K. L. (2015). Google classroom for librarians: features and opportunities. Library Hi Tech News, 32 (9), 1-3. https://doi.org/10.1 108/LHTN-05-2015-0039

Madhavi, B. K., Mohan, V., \& Nalla, D. (2018). Improving attainment of graduate attributes using google classroom. Journal of Engineering Education Transformations, 31 (3), 200- 
205. https://doi.org/10.16920/jeet/2018/v31i3/120792

Michotte, A. (2019). The Perception of Causality (1st ed). London: Routledge.

Mizell, H. (2014). Why Professional Development Matters. Journal of Contemporary Criminal Justice, 30 (4), 360-361. http://journals.sagepub.com/doi/10.1177/1043986214541602

Ocampo, J. F. G., Quevedo, M. C. J. A. C., Perez, C. A. O., \& Castillo, B. Y. M. (2017). Analysis of the use of Google Classroom in the students of System Engineering of the Instituto Tecnologico de Mexicali. European Journal of Multidisciplinary Studies, 6(2), 60. https://doi.org/10.26417/ejms.v6i2.p60-62

Qudratullah, Q., Aswinda, N., \& Najamuddin, N. (2020). Communication Patterns Of Coaches And Students In Cultivating Discipline Of Memorizing The Qur'an. INJECT (Interdisciplinary Journal of Communication), 5(1), 25-40. https://doi.org/10.18326/inject.v5i1.25-40

Ridho, D. M., Sawitri, I. D., \& Amatulloh, N. A. (2019). Students ' Perception Toward Google Classroom Application in EFL Classroom. Seminar Nasional Pendidikan, 1325-1332.

Rozak, A., \& Albantani, A. M. (2018). Desain Perkuliahan Bahasa Arab Melalui Google Classroom. Arabiyat: Jurnal Pendidikan Bahasa Arab Dan Kebahasaaraban, 5(1), 83102. https://doi.org/10.15408/a.v5i1.7481

Roxby, P. (2020, March 11). Coronavirus Confirmed as Pandemic by World Health Organization. BBC News. [United Kingdom]. Retrieved from https://www.bbc.com/news/world-51839944.

Sewang, A. (2017). Keberterimaan Google Classroom sebagai alternatif Peningkatan Mutu di IAI DDI Polewali Mandar. JPPI: Jurnal Pendidikan Islam Pendekatan Interdisipliner, 2(1), 35-46.

Soni, S., Hafid, A., Hayami, R., Fatma, Y., Wenando, F. A., Amien, J. Al, Fuad, E., Unik, M., Mukhtar, H., \& Hasanuddin, H. (2018). Optimalisasi Penggunaan Google Classroom, ELearning \& Blended Learning sebagai Media Pembelajaran Bagi Guru dan Siswa di SMK Negeri 1 Bangkinang. Jurnal Pengabdian UntukMu NegeRI, 2(1), 17-20. https://doi.org/10.37859/jpumri.v2i1.361

Ventayen, R. J. M., Estira, K. L., De Guzman, M. J., Cabaluna, C. M., \& Espinosa, N. N. (2018). Usability Evaluation of Google Classroom: Basis for the Adaptation of GSuite E-Learning Platform. Asia Pacific Journal of Education, Arts and Sciences, 5(1), 47-51. 


\section{Appendix}

Table 2. The instrument

\begin{tabular}{|c|c|c|c|c|c|}
\hline Factor & Questions & \multicolumn{4}{|c|}{ Scoring } \\
\hline & & $\mathrm{RD}$ & $\mathrm{D}$ & A & RA \\
\hline \multirow{4}{*}{ Usefulness } & $\begin{array}{l}\text { 1) Does this application help you become } \\
\text { more effective? }\end{array}$ & & & & \\
\hline & $\begin{array}{l}\text { 2) Does this application help you become } \\
\text { more productive? }\end{array}$ & & & & \\
\hline & 3) Is this application useful? & & & & \\
\hline & $\begin{array}{l}\text { 4) Does this application save time when you } \\
\text { use it? }\end{array}$ & & & & \\
\hline \multirow{6}{*}{ Ease of Use } & 5) Is this application easy? & & & & \\
\hline & 6) Is this application simple when it is used? & & & & \\
\hline & 7) Is this application user-friendly? & & & & \\
\hline & $\begin{array}{l}\text { 8) Do you use this application without written } \\
\text { instructions? }\end{array}$ & & & & \\
\hline & $\begin{array}{l}\text { 9) Can you use it to recover instantly when } \\
\text { making a mistake? }\end{array}$ & & & & \\
\hline & 10) Do you learn how to use it fast? & & & & \\
\hline $\begin{array}{l}\text { Ease of } \\
\text { Learning }\end{array}$ & 11) Do you easily remember how to use it? & & & & \\
\hline \multirow{5}{*}{ Satisfaction } & 12) Are you satisfied with this application? & & & & \\
\hline & 13) Is this application fun to use? & & & & \\
\hline & 14) Does this application work as expected? & & & & \\
\hline & 15) Is this application great? & & & & \\
\hline & 16) Is it convenient to use? & & & & \\
\hline
\end{tabular}

Note:

$\mathrm{RD}$ : Really Disagree

$D$ : Disagree

A : Agree

RA : Really Agree 